\title{
Subjective problems and temporomandibular disorders symptoms among musicians playing wind instruments
}

\author{
Subiektywne problemy i dolegliwości występujące w okolicy stawów \\ skroniowo-żuchwowych u muzyków grających na instrumentach dętych
}

\author{
Kamila Wróbel-Bednarz ${ }^{1}$, Agniesžka Drożdżyńska², \\ Elïbieta Kłosowska ${ }^{2}$, Aleksandra Ceglarska ${ }^{2}$, Rafal Korzeniewski ${ }^{2}$ \\ ${ }^{1}$ Department of Prosthetic Dentistry, Medical University of Warsaw \\ Katedra Protetyki Stomatologicznej, Warszawski Uniwersytet Medyczny \\ Head: prof. dr hab. n. med. Jolanta Kostrzewa-Janicka \\ ${ }^{2}$ Students' Research Group at the Department of Prosthetic Dentistry, Medical University of Warsaw \\ Studenckie Koło Naukowe przy Katedrze Protetyki Stomatologicznej, Warszawski Uniwersytet Medyczny
}

KEY WORDS:

TMD, wind instruments, musicians

\section{Summary}

Introduction. It is estimated that masticatory system disorders occur in even 40-90\% of the society, which classifies them as the most common dental problems. Postural disorders occurring in professional musicians, caused by frequently repeated non-physiological movements and the need to maintain asymmetrical postures for a long time, are described as the aetiological factors of playing-related musculoskeletal pain (PRMD). Musicians who play wind instruments are particularly vulnerable to the occurrence of ailments from the stomatognathic system, including those affecting the temporomandibular joints.

Aim of the study. To analyse the problems and ailments occurring in the region of temporomandibular joints of musicians playing brass and wood instruments.

Material and methods. The research consisted in conducting a survey addressed to people who play wind instruments. The questionnaire included general questions about playing the instrument, the observed symptoms of dysfunction, and the
HASŁA INDEKSOWE:

dysfunkcje skroniowo-żuchwowe, instrumenty dęte, muzycy

\section{Streszczenie}

Wprowadzenie. Szacuje sie, że problemy w obrębie narzadu żucia, występuja nawet u 40-90\% społeczeństwa, co pozwala zakwalifikować je do grupy najczęstszych chorób stomatologicznych. Zaburzenia postawy, wystepujace u zawodowych muzyków, wywotane często powtarzanymi niefizjologicznymi ruchami i utrzymywaniem asymetrycznych pozycji ciała przez dlugi czas, opisywane sa jako czynniki etiologiczne zaburzeń mięśniowo-szkieletowych (PRMD - playing - realated muskuloskeletal pain). Na wystepowanie dolegliwości ze strony układu stomatognatycznego, w tym stawów skroniowo-żuchwowych szczególnie narażeni sa muzycy grający na instrumentach dętych, m.in. ze względu na wzmożone napięcie mięśniowe.

Cel pracy. Celem pracy byta analiza problemów i dolegliwości wystepujacych w okolicy stawów skroniowo-żuchwowych (TMD) u muzyków grajacych na instrumentach dętych blaszanych oraz drewnianych.

Material i metody. Badanie polegało na przeprowadzaniu ankiety, kierowanej do osób związa- 
use of preventive measures. The obtained data were statistically analyzed.

Results. A total of 1067 filled questionnaires were collected from 49 countries around the world. According to the study, musicians playing woodwinds constitute a group particularly vulnerable to develop dysfunction. Symptoms of TMD are more common in musicians who play professionally, and they are characteristic of women.

Conclusions. 1. Playing wind instruments may predispose musicians to suffer from ailments and disorders of the temporomandibular joints. 2. Professional musicians, who practise for many hours a day are particularly vulnerable, as well as those who play woodwind instruments. 3. Warming up before performing can help prevent some ailments. 4. Musicians who play woodwind instruments require special dental care. 5. Education regarding proper habits and implementation of prophylactic measures is important.

\section{Introduction}

Dysfunctions of the stomatognathic system constitute a disorder that nowadays affects an increasing percentage of the population, especially people exposed to constantcivilization stress, as a consequence of increasing nervous pressure. ${ }^{1,2}$ According to the current research, it is estimated that problems within the masticatory system occur in even $40-90 \%$ of the society, which allows one to classify them, along with caries and periodontal diseases, as the most common dental diseases, sometimes referred to as social diseases. ${ }^{3}$ Functional disorders in the masticatory organ such as muscle and/ or TMJ area pain, abnormal mobility of the mandible (caused by the incorrect mobility of TMJ structures) and sound symptoms form a group which is described in the literature as nych z gra na instrumentach dętych. $W$ ankiecie zawarto pytania ogólne, dotyczace gry na instrumencie, zaobserwowanych objawów dysfunkcji, stosowania zabezpieczenia profilaktycznego. Otrzymane dane poddano analizie statystycznej.

Wyniki. Zebrano 1067 ankiet z 49 państw świata. Wedlug przeprowadzonego badania szczególnie narażona grupa na rozwój dysfunkcji sa muzycy grajacy na instrumentach dętych drewnianych. Objawy TMD częściej występuja u muzyków grajacych zawodowo, charakterystyczne sa dla kobiet.

Wnioski. 1. Gra na instrumentach dętych może predysponować do wystepowania objawów dysfunkcji skroniowo-żuchwowych. 2. Szczególnie narażeni na występowanie TMD sa muzycy grajacy zawodowo, osoby ćwiczace gre codziennie przez wiele godzin oraz muzycy, którzy wybrali instrument dęty drewniany. 3. Rozgrzewka przed gra może pomóc w zapobieganiu dolegliwościom. 4. Muzycy grajacy na instrumentach dętych należa do grupy pacjentów, która wymaga szczególnej opieki stomatologicznej. 5. Właściwa edukacja oraz wdrożenie ewentualnych działań i nawyków profilaktycznych jest wskazana.

\section{Wstęp}

Dysfunkcje układu stomatognatycznego są zaburzeniami, które w dzisiejszych czasach dotyczą coraz większego odsetka populacji, w tym zwłaszcza osób narażonych na ciągły stres cywilizacyjny powodujący w następstwie zwiększenie napięcia nerwowego. ${ }^{1,2}$ Według aktualnych badań szacuje się, że problemy w obrębie narządu żucia, występują nawet u 40-90\% społeczeństwa, co pozwala zakwalifikować je razem z próchnicą i chorobami przyzębia do grupy najczęstszych chorób stomatologicznych, niekiedy określanych mianem chorób społecznych. ${ }^{3}$ Zaburzenia czynnościowe $\mathrm{w}$ obrębie układu ruchowego narządu żucia, takie jak ból w obrębie mięśni i/lub stawów skroniowo-żuchwowych, nieprawidłowe tory i zakresy ruchów żuchwy 
a "classic triad". 4 The most common causes of myoarthropathy include: occlusal and nonocclusal parafunctions, occlusal abnormalities, joint injuries, postural disturbances and systemic factors. ${ }^{5}$

Incorrect postures of the professional musicians are caused by frequent nonphysiological movements and the need to maintain asymmetric, unnatural positions of the body for a long period of time. They are described as aetiological factors of musculoskeletal disorders (PRMD - playingrelated musculoskeletal pain). The literature states that even $86 \%$ of professional musicians suffer from PRMD. The main area of pain occurrence is the neck, regardless of the type of instrument the musician is playing. In the study conducted by Steinmetz et al. such ailments have been the most frequent among examined female respondents and the musicians, who played every day. Professional musicians are the main group, in which we can observe permanent and very intense pain. Furthermore, about $40 \%$ of musicians suffer from pain in as many as five different areas of the body. ${ }^{6}$

Musicians who play wind instruments are particularly vulnerable to the occurrence of ailments from the stomatognathic system, including temporomandibular joints, due to the increased muscle tension, especially when playing high tones on brass instruments. ${ }^{7}$ Considering masticatory organ dysfunction, the necessity of increased ventilation, higher activity of the head and neck muscles, for example muscles hypertonia when high tones are played (especially on brass instruments) and mandible protrusive position may lead to parafunctions and major problems of the temporo-mandibular joints (TMJ). ${ }^{8}$

\section{The aim of the study}

The aim of the study was to analyse the problems and ailments occurring in the area (wynikająca z zaburzonej pracy stawów skroniowo-żuchwowych) oraz towarzyszące im objawy dźwiękowe, tworzą opisywaną w piśmiennictwie tzw. „klasyczną triadę objawów". ${ }^{4}$ Do najczęstszych przyczyn mioartropatii zaliczane są: parafunkcje zwarciowe i niezwarciowe, nieprawidłowości okluzyjne, urazy w obrębie stawów, zaburzenia postury oraz czynniki ogólnoustrojowe. ${ }^{5}$

Zaburzenia postawy, występujące u zawodowych muzyków, wywołane często powtarzanymi niefizjologicznymi ruchami i utrzymywaniem asymetrycznych pozycji ciała przez długi czas, opisywane są jako czynniki etiologiczne zaburzeń mięśniowo-szkieletowych (PRMD - playing - realated muskuloskeletal pain). Piśmiennictwo podaje, że cierpi na nie nawet $86 \%$ profesjonalnie grających muzyków. Głównym obszarem dolegliwości bólowych jest szyja, niezależnie od instrumentu, na którym gra muzyk. W badaniach Steinmetza $i$ wsp. dolegliwości występowały zdecydowanie częściej u badanych kobiet w stosunku do mężczyzn oraz u muzyków grających zawodowo niż amatorów. Profesjonaliści stanowią główną grupę, u której obserwuje się permanentnie utrzymujący się ból o dużym stopniu nasilenia. Ponadto około 40\% muzyków odczuwa dolegliwości nawet $\mathrm{w}$ ponad pięciu różnych obszarach ciała. ${ }^{6}$

$\mathrm{Na}$ występowanie dolegliwości ze strony układu stomatognatycznego, w tym stawów skroniowo-żuchwowych szczególnie narażeni są muzycy grający na instrumentach dętych, m.in. ze względu na wzmożone napięcie mięśniowe obecne zwłaszcza podczas gry wysokich tonów na instrumentach dętych blaszanych. ${ }^{7}$ Konieczność utrzymania zwiększonej wentylacji, nasilonej aktywności mięśni głowy i szyi oraz położenia żuchwy w protruzyjnej pozycji, mogą prowadzić do rozwoju bruksizmu oraz poważnych problemów w obrębie stawów skroniowo-żuchwowych. ${ }^{8}$ 
of the temporomandibular joints of musicians playing brass and wood instruments.

\section{Materials and methods}

In the study a survey was addressed to the people who play wind instruments through internet-themed forums and interest groups for the musicians in Poland and abroad. Surveys were collected using CAWI (Computer-Assisted Web Interview) method in two languages: Polish and English.

The questionnaire consisted of 50 questions (46 structured questions and 4 open ones). Questions about primary data such as: sex, age and the type of instrument the interviewee played were asked. Also questions about when musicians started to play the instrument, how often and what the duration of practice during a day was were asked. There were also questions about age when they started playing systematically and if playing was their regular profession. Among all questions thirteen were about TMJ complaints. Questions about the occurrence of the "classic triad" - "jaw joints problems" such as: pain, "crackles or popping" and mandible movement limitation on a daily basis and also while playing a wind instrument were asked. Other questions concerned ailments during movement of mandible during chewing. The information concerning occlusal toothwear, grinding of teeth, habitual clenching of teeth at night [9], the use of relaxation occlusal splints and the incidence of head pain and head and neck muscles pain were collected. The respondents also answered if they warmed-up before practice and if they regularly attended follow-up dental visits. Questions of whether they had been informed by a dentist about specific dental problems which may occur in the group of wind instrument players, and how to prevent conditions in the masticatory system typical of that group were also asked.

\section{Cel pracy}

Celem pracy była analiza problemów i dolegliwości występujących w okolicy stawów skroniowo-żuchwowych u muzyków grających na instrumentach dętych blaszanych oraz drewnianych.

\section{Materiały i metody}

Badanie polegało na przeprowadzaniu poprzez tematyczne fora internetowe ankiety, kierowanej do osób związanych z grą na instrumentach dętych oraz grup zainteresowań w Polsce i na świecie. Ankiety zbierano metodą CAWI (Computer-Assisted Web Interview) w dwóch wersjach językowych - w języku polskim i angielskim.

Ankieta składała się z 50 pytań (46 zamkniętych i 4 otwartych). Zadano między innymi podstawowe pytania dotyczące płci, wieku oraz rodzaju instrumentu, na którym grał ankietowany. Zapytano również od ilu lat, jak często i ile średnio godzin dziennie grają respondenci. W ankiecie zawarto także pytania o wiek, w którym muzycy rozpoczęli systematyczną grę, a także czy gra na instrumencie dętym stanowi ich wykonywany na co dzień zawód. Wśród pytań zadanych ankietowanym trzynaście odnosiło się bezpośrednio do możliwości występowania dolegliwości ze strony stawów skroniowo-żuchwowych (SSŻ). Ankieta uwzględniała pytania dotyczące występowania „klasycznej triady” objawów: bólu okolicy ucha, ograniczenie ruchów żuchwy, zaobserwowanie przez pacjenta trzasków i przeskakiwań w stawie podczas gry. Uwzględniono także pytania dotyczące występowania dolegliwości podczas wykonywania ruchów żuchwy, w tym w trakcie żucia pokarmów. Zebrano również informacje na temat występowania nadmiernego starcia zębów, zgrzytania zębami, nawykowego zaciskania zębów w nocy, stosowania szyn relaksacyjnych oraz częstości pojawiania się bólu 
Received data were submitted for statistical analysis by using statistical tests. Using Pearson's Chi-square and/or Pearson's Chisquare test with Yates' correction of continuity, data dependency (connection) between sexes and type of the instrument: playing techniques, duration of playing in years, age of starting playing, frequency of practice, duration of practice in hours, professional playing, doing warm-ups, occurrence of the "classic triad", head and neck muscles pain and probable symptoms of bruxism (occlusal wear, grinding or clenching teeth) and using splint at night. In selected problems other indicators were additionally used. To determine the connection between the age of starting playing the instrument, frequency of practice and sex the Mann-Whitney-Wilcoxon test was used. Also to see the relation between professional playing and sex the Wilcoxon test with continuity correction was used. In analysis of connection between occurrence pain in TMJ and duration of playing, as well as decreased mobility of the mandible the Wilcoxon test with continuity correction and Kruskal-Wallis test were used (beside Pearson's Chi-square test). To determine dependency of frequency of practice on the occurrence of clicking in TMJ and muscle pain also three tests were used: Pearson's Chi-square, Wilcoxon test with continuity correction and Kruskal-Wallis test. In all the cases the statistical significance level was routinely established at $p<0.05$. In analysis of respondents' age quantiles cut, average, median, modal, standard deviation and ShapiroWilk normality test were determined (Tab. 1).

\section{Results}

In the study, 1067 filled questionnaires from 49 countries were collected. The largest amount was from Poland (531), with the USA (295) taking the second place. After rejecting incorrectly completed ones, 1059 correctly głowy i bólu mięśniowego w obrębie głowy i szyi. Respondenci odpowiadali czy przed rozpoczęciem gry stosują jakąkolwiek formę rozgrzewki, a także czy regularnie zgłaszają się na wizyty kontrolne do lekarza dentysty oraz czy zostali poinformowani o specyficznych problemach stomatologicznych mogących wystąpić u muzyków grających na instrumentach dętych oraz w jaki sposób postępować by nie dopuścić do powstania typowych dla tej grupy dolegliwości w obrębie układu stomatognatycznego.

Otrzymane dane poddano analizie statystycznej. Przy użyciu testu Pearsona Chi-kwadrat i/ lub testu Pearsona Chi-kwadrat z poprawką na ciągłość Yatesa, określono zależności płci oraz grupy instrumentów wobec: sposobu gry, liczby lat grania, wieku rozpoczęcia gry, częstości praktykowania, liczby godzin ćwiczeń gry, zawodowej gry, stosowania rozgrzewki, występowania „klasycznej triady objawów”, bólu w okolicy głowy i szyi, a także objawów mogących świadczyć o bruksizmie: starcia zębów, zaciskania zębów, zgrzytania, jak również stosowania szyny relaksacyjnej. W wybranych przypadkach dodatkowo stosowano inne wskaźniki. W określeniu zależności wieku rozpoczęcia gry na danym instrumencie oraz zależności częstości gry według płci zastosowano test Manna-Whitneya-Wilcorona. Do ustalenia zależności gry zawodowej od płci zastosowano także test Wilcoxona z poprawką na ciągłość. W analizie zależności długości gry od występowania bólu stawu, a także długości gry od występowania ograniczonej ruchomości żuchwy zastosowano oprócz testu Pearsona Chikwadrat, test Wilcoxona z poprawką na ciągłość oraz test Kruskal-Wallis. W analizie zależności częstości gry wobec występowania objawów dźwiękowych oraz zależności częstości gry wobec bólu mięśniowego również zastosowano trzy testy: test Pearsona Chi-kwadrat, test Wilcoxona z poprawką na ciągłość oraz test Kruskal-Wallis. We wszystkich przypadkach standardowo za próg istotności statystycznej 
Table 1. Respondents' age analysis

\begin{tabular}{|c|c|c|c|}
\hline Average age & Median age & Modal age & Standard deviation \\
\hline 28 & 23 & 18 & 13.4280863 \\
\hline
\end{tabular}

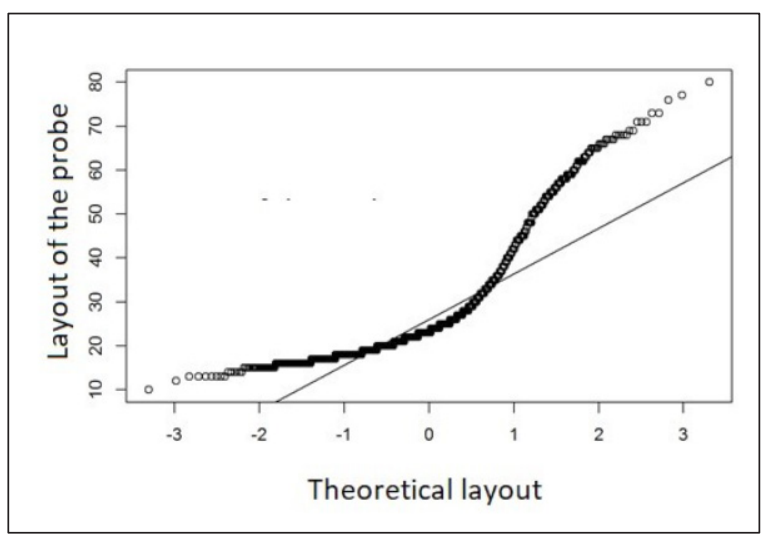

Fig. 1. Age analysis of respondents - quantile distribution of the sample vs. theoretical distribution. Ryc. 1. Analiza wieku respondentów - rozkład kwantylowy próby vs rozkład teoretyczny.

filled questionnaires were obtained. The study group thus constituted 1059 subjects, including 367 women (35\%) and 692 men (65\%). As much as $75 \%$ of the examined were aged under 34 years (Fig. 1). The respondents were divided into two groups depending on the type of the wind instrument: woodwind instrument $-44 \%$ and brass instrument $-56 \%$ of the musicians.

In the survey, the information about frequency of the practice and since when the musician had played an instrument was collected. It emerged that $86 \%$ of the respondents had been playing for at least 6 years of which $49.7 \%$ were practicing daily, and $56.2 \%$ were playing for $1-2$ hours a day. Among all respondents, there were 19\% more men practising daily comparing to women. Also musicians who played brass instruments practised more in comparison with musicians playing other types of wind instruments. $60 \%$ of respondents declared professional playing (musicians with at least 10-years' experience). Within this group, there were $12 \%$ more men przyjęto $\mathrm{p}<0,05$. W analizie wieku respondentów określano rozkład kwartylowy, średnią, medianę, modalną, odchylenie standardowe oraz test normalności rozkładu Shapiro-Wilka (tab. 1).

\section{Wyniki}

Łącznie zebrano 1067 ankiet z 49 państw świata. Najwięcej ankiet pochodziło z Polski (531), natomiast na drugim miejscu pod względem liczby - ze Stanów Zjednoczonych (295). Po odrzuceniu błędnie wypełnionych ankiet, grupę badaną stanowiło 1059 osób w tym 367 kobiet (35\%) i 692 mężczyzn (65\%). Aż 75\% badanych to osoby w wieku poniżej 34 roku życia (ryc. 1). Ankietowani zostali podzieleni na dwie grupy w zależności od rodzaju instrumentów dętych, na których grają: dęty drewniany $-44 \%$ i dęty blaszany $-56 \%$.

W ankiecie zadano pytania odnośnie częstotliwości gry oraz długości stażu grającego. Okazało się, że $86 \%$ ankietowanych gra na instrumencie co najmniej 6 lat. Codziennie ćwiczy $49,7 \%$ badanych, a $56,2 \%$ gra przez $1-2$ godziny dziennie. Każdego dnia na instrumencie dętym ćwiczy o 19\% więcej mężczyzn niż kobiet. Więcej praktykują również muzycy grający na instrumentach dętych blaszanych, 60 \% osób przyznaje, że zawodowo gra na instrumencie dętym (muzycy z co najmniej 10-letniem doświadczeniem). Grę jako pracę zawodową zgłaszają częściej mężczyźni niż kobiety (różnica wynosi 12\%). Większość zawodowych muzyków to profesjonaliści grający na instrumentach dętych blaszanych, chociaż nie stanowią oni dużo liczniejszej grupy niż muzycy wybierający instrumenty dęte drewniane. W 
Ta b 1e 2. Musicians playing frequency

\begin{tabular}{|c|c|c|c|c|c|}
\hline & $\begin{array}{c}\text { Less than once } \\
\text { a week }\end{array}$ & $\begin{array}{c}1-2 \text { times } \\
\text { a week }\end{array}$ & $\begin{array}{c}3-4 \text { times } \\
\text { a week }\end{array}$ & $\begin{array}{c}5-6 \text { times } \\
\text { a week }\end{array}$ & $\begin{array}{c}\text { Every } \\
\text { day }\end{array}$ \\
\hline $\begin{array}{c}\text { Number of } \\
\text { people }\end{array}$ & 42 & 128 & 169 & 193 & 527 \\
\hline
\end{tabular}

than women. The majority of professionals were musicians who played brass instruments, though this group was not much bigger than the group of musicians who played woodwind instruments. In the examined group of the professionals, the majority $(62.5 \%)$ practised daily and $82 \%$ declared practising for more than 4 hours a day (Tab. 2).

Every fifth respondent reported everyday complaints originating in the temporomandibular joint. The first problem from the "classic triad" was pain in the area of the TMJ on playing. After analysing the survey, the authors of the present study have observed that the complaint was more common in the group of the professional musicians $(58 \%)$, as well as in the group of female musicians (18\%) (Fig. 2). Moreover, the frequency of practising turned out to be an important factor in the appearance of pain, but interestingly the duration of practice was not statistically significant. The second characteristic symptom reported by about $15 \%$ of the respondents was limited mobility of the mandible when an instrument was played. The problem concerned over $20 \%$ of women and about $10 \%$ of men. According to this study, the group most susceptible to these ailments consisted of the musicians who played woodwind instruments, especially the oboe and the bassoon. About 9\% of the musicians (majority of the professional musicians (51\%), and also women performers (54\%) admitted that they noticed "crunches and popping" in the TMJ (Fig. 3).

The respondents were also asked, if they were doing any type of muscle warm-up before a long play to prevent TMJ complaints. A warm-up was performed by about $47 \%$ of the examined badanej grupie zawodowców większość (62,5 \%) gra codziennie, a $82 \%$ deklaruje, że ćwiczy dłużej niż 4 h dziennie (tab. 2).

Codziennie występujące dolegliwości ze strony stawów skroniowo-żuchwowych podaje co piąty ankietowany. Pierwszym problemem z klasycznej triady objawów, który zgłaszają muzycy jest ból w okolicy stawów, występujący podczas gry. Z przeprowadzonego badania ankietowego wynika, że częściej występuje on u muzyków grających zawodowo (58\%), jak również u kobiet (18\%), (ryc. 2). Ponadto okazało się, że ważnym czynnikiem indukującym dolegliwości bólowe jest częstość ćwiczeń, przy czym co interesujące, czas ich trwania nie wykazuje już w tym wypadku jakiejkolwiek istotności statystycznej. Drugim charakterystycznym objawem zgłaszanym przez $15 \%$ respondentów jest ograniczenie ruchomości żuchwy podczas gry. Z analizy wynika, że występuje ono u $20 \%$ kobiet oraz $10 \%$ mężczyzn. Według przeprowadzonego badania szczególnie narażoną grupą na tego typu dolegliwości są muzycy grający na instrumentach dętych drewnianych, a zwłaszcza na oboju i fagocie. Zaledwie 9\% muzyków, w przewadze muzyków zawodowych (51\%) oraz kobiet (54\%) przyznało, że zauważyło u siebie występowanie objawów dźwiękowych w postaci trzasków, trzeszczeń lub przeskakiwań (ryc. 3).

Respondentom zadano również pytanie czy na co dzień stosują jakąkolwiek formę rozgrzewki mięśniowej przed długotrwałą grą, w celu zapobiegania dolegliwościom ze strony stawów skroniowo-żuchwowych. Rozgrzewkę stosowało $47 \%$ badanych, w tym $29 \%$ podaje, że robi to często - głównie byli to mężczyźni 


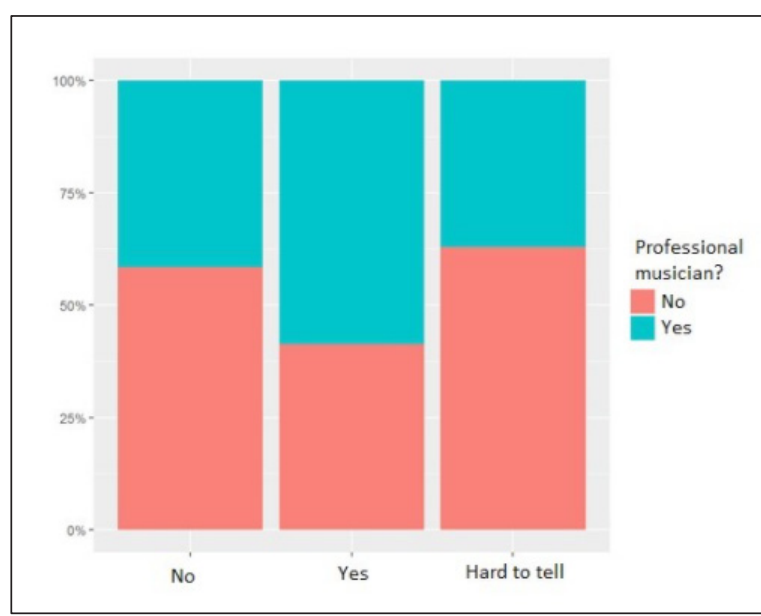

Fig. 2. Pain in the area of the temporomandibular joint in professional musicians group.

Ryc. 2. Ból w okolicy stawu skroniow-żuchwowego u zawodowych muzyków.

group, of which $29 \%$ admitted doing it regularly - mostly men (67\%) and brass instruments players (68\%). Professional musicians (42\%) and musicians who declared that they were practising daily (59\%) often warmed up as well. The analysis of the results has demonstrated that $17 \%$ of the respondents reported excessive occlusal wear of teeth, $29 \%$ habitual grinding of teeth and $33 \%$ would unconsciously grind their teeth at night. Even though the patients themselves frequently noticed different types of parafunctions, occlusal relaxation splint was used only by $5 \%$. On the grounds of the results, it can be concluded that the gender factor has the biggest influence on the development of probable bruxism - women more often displayed parafunctions. Other factors such as frequency of practice, duration of playing or experience were not statistically significant.

There were questions in the survey about dysfunctions in the TMJ, which can occur as pain in some other areas of the head and neck (not only TMJ area), e.g. manifesting as headaches, which were confirmed by about $68 \%$ of the respondents. Moreover, $24 \%$ of all the examined musicians were people suffering from headaches that

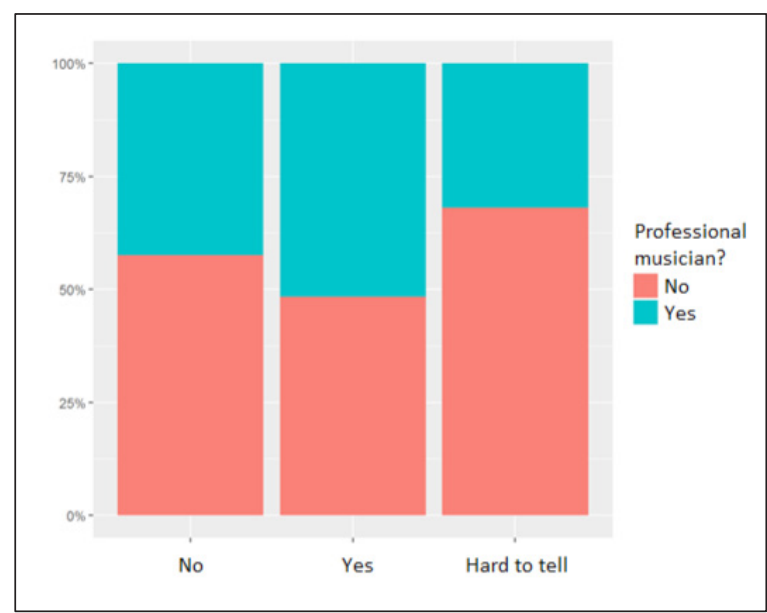

Fig. 3. Occurrence of auditory symptoms in professional musicians.

Ryc. 3. Występowanie objawów dźwiękowych u zawodowych muzyków.

(67\%) oraz osoby grające na instrumentach blaszanych (68\%). Stosunkowo często rozgrzewają się również muzycy zawodowi (42\%) oraz osoby, które deklarują, że grają codziennie przez wiele godzin (59\%). Analiza wyników wykazała, że 17\% respondentów zgłasza nadmierne starcie zębów, 29\% nawykowe zaciskanie, a najwięcej ankietowanych, bo aż 33\% - zgrzyta zębami w nocy. Mimo częstego zaobserwowania przez pacjentów różnorodnych form parafunkcji, szynę relaksacyjną stosowało zaledwie $5 \%$. Na podstawie wyników można stwierdzić, że największy wpływ na częstość potencjalnego występowania i rozwoju bruksizmu ma płeć - kobiety częściej raportują wymienione parafunkcje. Pozostałe czynniki, takie jak częstość, długość gry czy doświadczenie (zawodowi muzycy) nie były znaczące statystycznie.

Spośród innych lokalizacji bólowych - występowanie bólu głowy potwierdziło $68 \%$ osób. Ponadto $24 \%$ wszystkich badanych stanowią osoby cierpiące na bóle głowy, pojawiające się minimum raz w tygodniu. Kobiety w tym przypadku stanowią zdecydowaną większość (tab. 3). Kolejną grupą objawów mogących 
Ta b le 3. The incidence of headache

\begin{tabular}{|c|c|c|c|c|c|}
\hline & $\begin{array}{c}\text { A few times } \\
\text { a week }\end{array}$ & $\begin{array}{c}\text { Once } \\
\text { a week }\end{array}$ & $\begin{array}{c}\text { Less than once } \\
\text { a week }\end{array}$ & $\begin{array}{c}\text { Always after } \\
\text { playing }\end{array}$ & Never \\
\hline Women & $19 \%$ & $18 \%$ & $44 \%$ & $1 \%$ & $18 \%$ \\
\hline Men & $8 \%$ & $9 \%$ & $43 \%$ & $<1 \%$ & $39 \%$ \\
\hline
\end{tabular}

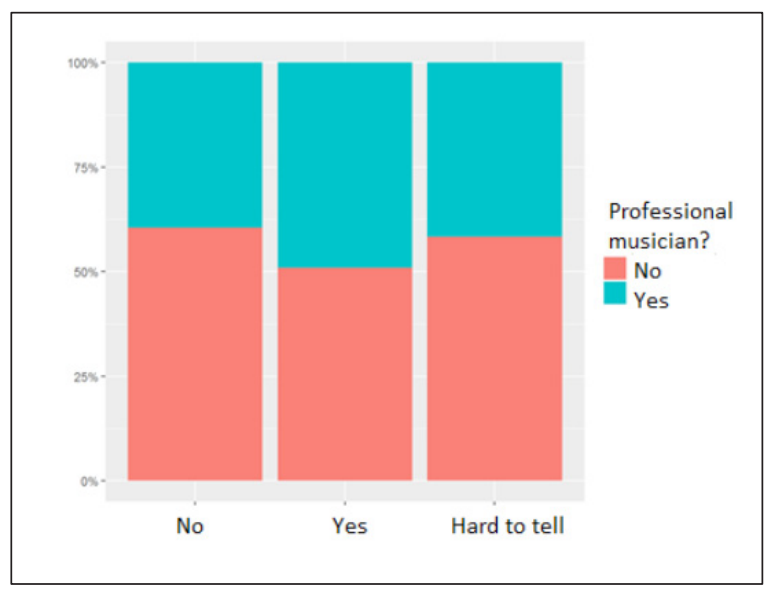

Fig. 4. The prevalence of muscle pain in professional musicians.

Ryc. 4. Występowanie bólu mięśniowego u zawodowych muzyków.

occurred minimum once a week, and here women constituted the majority (Tab. 3). Another issue concerned muscle pain accompanying disorders in the TMJ. In their answers, a large number of the respondents paid particular attention (especially in open questions) to the occurrence of recurrent pain and muscle cramps mostly of the neck muscles. The analysis of the results demonstrated that pain occurred in $21 \%$ of the examined subjects, mostly among woodwind instruments players (56\%). This problem mainly appears in the group of musicians who played: the oboe, the western concert flute and the French horn. Moreover, professional players (50\%) and female players $(39 \%)$ quite often complained of pain. Additionally, the occurrence of the muscle pain during chewing was examined about $7 \%$ of the respondents reported this ailment (Fig. 4, 5).

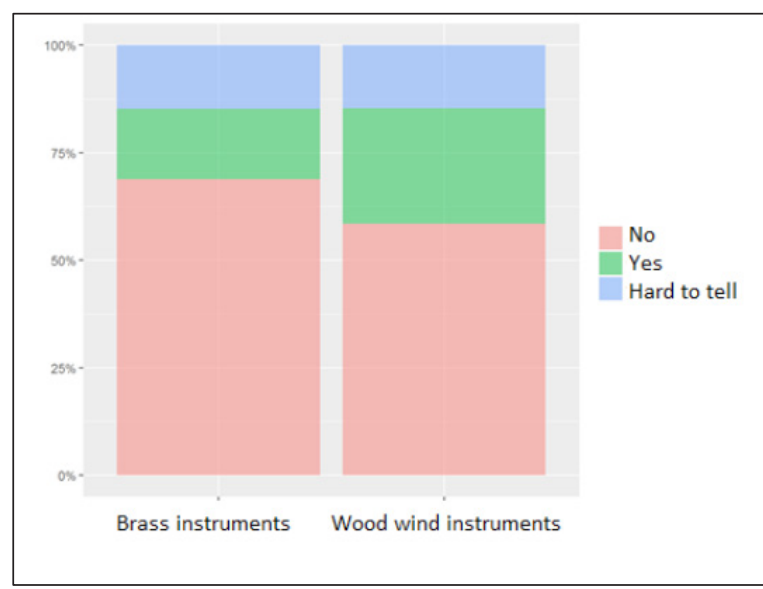

Fig. 5. The occurrence of muscle pain acc. to the group of instruments.

Ryc. 5. Występowanie bólu mięśniowego wg grupy instrumentów.

towarzyszyć zaburzeniom stawów skroniowo-żuchwowych, o które pytani byli ankietowani są bóle mięśniowe. Bardzo duża liczba respondentów zwracała uwagę w swoich odpowiedziach (zwłaszcza w pytaniach otwartych) na występowanie nawracającego bólu i skurczu mięśni głównie w rejonie szyi i karku. $\mathrm{Na}$ podstawie analizy wyników okazało się, że ból o takim charakterze występuje u $21 \%$ badanych, najczęściej wśród osób grających na instrumentach dętych drewnianych (56\%). Problem ten dotyka zwłaszcza muzyków wybierających obój, flet poprzeczny oraz waltornię. Ponadto na ból uskarżają się również często profesjonalni muzycy (50\%) oraz kobiety (39\%). Dodatkowo zapytano czy ból pojawiał się także podczas aktu żucia, w odpowiedzi zaledwie $7 \%$ ankietowanych zgłosiło występowanie takich dolegliwości (ryc. 4, 5). 


\section{Discussion}

Dysfunctions of the motor system of the masticatory organ are characterized by a very diverse clinical picture, with a different number, frequency and intensity of symptoms. An increased risk of dysfunction in the stomatognathic system is observed in large urban agglomerations with a high degree of industrialization, while at the same time other social factors, such as: living conditions, marital status and the ability to relax, do not show a statistically significant influence. ${ }^{1}$ It has been estimated that problems within the masticatory system may occur in even $40-90 \%$ of the population, including women in the 2040 age group, who are much more likely to suffer from disorders. Moreover, there is an increase in the incidence of dysfunctions in very young people, from the age of $7(30 \%-$ $60 \%$ ) to the age of 19 years (even $80 \%) .{ }^{9}$

Over the years, numerous attempts to establish the unequivocal etiopathogenesis of disorders of the masticatory system have resulted in the emergence of many theories which have helped to establish today's knowledge on the factors predisposing to disorders of the masticatory system. The mechanistic concept indicated mainly malocclusion as the cause of the abovementioned ailments. In turn, in the myofascial theory and the pain-dysfunctional syndrome of the temporomandibular joints, the main cause was seen in increased muscle tension within the masticatory muscles and premature occlusal contacts resulting from increased emotional tension. The methods of treatment proposed at thattimewere to bebased primarily on therapeutic exercises and the reconstruction of occlusal conditions. Then, in the psychophysiological theory, particular emphasis was placed on the psychological factor and habits that the patient often acquired in order to relieve stress. As a result of subsequent studies, the concept of previous researchers was supplemented with

\section{Dyskusja}

Dysfunkcje układu ruchowego narządu żucia charakteryzuje bardzo zróżnicowany obraz kliniczny, o różnej liczbie, częstotliwości i natężeniu występowania objawów. Podwyższone ryzyko pojawienia się dysfunkcji w układzie stomatognatycznym obserwuje się $\mathrm{w}$ dużych aglomeracjach miejskich, o wysokim stopniu industrializacji, podczas gdy jednocześnie inne czynniki socjalne, takie jak: warunki zamieszkania, stan cywilny oraz umiejętność relaksacji okazują się nie wykazywać istotnego statystycznie wpływu. ${ }^{1}$ Oszacowano, że problemy w obrębie narządu żucia, mogą występować nawet u 40$90 \%$ społeczeństwa, w tym kobiety w przedziale wiekowym 20-40 lat stanowią grupę, u której problem zaburzeń występuje znacznie częściej. Ponadto obserwuje się wzrost częstości występowania dysfunkcji u osób w bardzo młodym wieku, już od 7 roku życia (30\% - 60\%) do 19 roku życia (nawet $80 \%)^{9}$

Na przestrzeni lat liczne próby ustalenia jednoznacznej etiopatogenezy zaburzeń narządu żucia zaowocowały powstaniem wielu teorii, które pozwoliły na ukształtowanie się dzisiejszej wiedzy dotyczącej czynników predysponujących do powstania zaburzeń układu ruchowego narządu żucia. Mechanistyczna koncepcja jako przyczynę występowania powyższych dolegliwości wskazywała głównie wady zgryzu. Z kolei w teorii mięśniowo-powięziowej oraz zespole bólowo-dysfunkcyjnym stawów skroniowo-żuchwowych, jako główną przyczynę upatrywano w zwiększonym napięciu mięśniowym w obrębie mięśni żucia oraz przedwczesnych kontaktach zwarciowych, wynikających ze wzmożonego napięcia emocjonalnego. Proponowane wówczas metody leczenia, miały opierać się przede wszystkim na ćwiczeniach terapeutycznych oraz odbudowie warunków zwarciowych. Następnie $w$ teorii psychofizjologiczej, szczególny nacisk położono na czynnik psychologiczny oraz nawyki, które 
neuromuscular dependencies, which enabled the development of a biopsychosociological theory, which recognizes three main factors as important causes of the stomatognathic system disorders: biological, psychological and sociological. In the following years, hormonal disorders (intra-articular estrogens, modifying metabolism and pain sensations), metabolic disorders and individual adaptation and compensatory abilities of the patient's organism were added to the multifactorial aetiology of the stomatognathic system dysfunction. The conclusion was that the most advanced lesions occured in elderly people with reduced regenerative abilities. $3,9,10$

Functional disorders of the masticatory system constitute the "the classic triad of symptoms". In addition, the above symptoms were found to be associated with increased tension and soreness of the muscles of the head and neck, as well as the shoulder belt, and even the chest or upper limbs. ${ }^{4}$ Based on the descriptions of electromyographic studies of the masticatory muscles, it can be concluded that the asymmetric work of the muscles and their increased bioelectrical activity may predispose to disorders in the temporomandibular joints. ${ }^{11,12}$ The presence of para-functions (occlusal and non-occlusal) contributes to the asymmetrical work of the muscles and, consequently, to the appearance of overloads and microtraumas. ${ }^{14}$ Postural disorders, through their impact on the muscles of the head and neck, can lead to disorders in the masticatory system. On the other hand, occlusal pathologies and the lack of support zones may, through the muscles of the neighbouring areas, lead to asymmetrical tensions in the muscles responsible for body posture. Ailments from the "classic triad" may be accompanied by disease symptoms of other organs from close areas, such as headaches, pains in the eyeball and orbit, eyeball blowouts, otolaryngological disorders, including earaches, tinnitus. Mutual często pacjent nabywał w celu możliwości rozładowania stresu. W wyniku kolejnych badań uzupełniono myśl poprzednich badaczy o zależności neuromięśniowe, co pozwoliło na powstanie teorii biopsychosocjologicznej, która za istotne przyczyny zaburzeń układu stomatognatycznego uznaje przede wszystkim trzy główne czynniki: biologiczny, psychologiczny oraz socjologiczny. W następnych latach do wieloczynnikowej etiologii dysfunkcji układu stomatognatycznego dodano także zaburzenia hormonalne (estrogeny wytwarzane wewnątrzstawowo, modyfikujące metabolizm oraz doznania bólowe), zaburzenia metaboliczne oraz indywidualne możliwości adaptacyjne i kompensacyjne organizmu danego pacjenta W konkluzji podano, iż najbardziej zaawansowane zmiany występują u osób starszych ze zmniejszonymi zdolnościami regeneracyjnymi. ${ }^{3,9,10}$

Zaburzenia czynnościowe w obrębie układu ruchowego narządu żucia tworzą opisywaną w piśmiennictwie tzw. „klasyczną triadę objawów". Ponadto zaobserwowano współwystępowanie powyższych objawów ze zwiększonym napięciem i bolesnością uciskową mięśni w obrębie głowy i szyi, jak również pasa barkowego, a nawet klatki piersiowej czy kończyn górnych. ${ }^{4}$ Na podstawie opisów badań elektromiograficznych poszczególnych mięśni żucia wywnioskować można, że asymetryczna praca mięśni oraz ich podwyższona aktywność bioelektryczna predysponować mogą do wystąpienia zaburzeń w obrębie stawów skroniowo-żuchwowych. ${ }^{11,12}$ Obecność parafunkcji zwarciowych i niezwarciowych przyczynia się do niesymetrycznej pracy mięśni oraz w następstwie do pojawienia się przeciążeń i mikrourazów. ${ }^{13}$ Zaburzenia posturalne poprzez wpływ na mięśnie głowy i szyi mogą prowadzić do zaburzeń w obrębie narządu żucia. Natomiast nieprawidłowości zgryzowe oraz brak stref podparcia mogą poprzez mięśnie sąsiednich okolic doprowadzić do niesymetrycznych napięć mięśni odpowiadających za postawę ciała. ${ }^{14}$ Dolegliwościom z ,klasycznej 
functional relations of individual structures of the stomatognathic system and organs of the closely localized anatomical regions, as well as the complex etiology of dysfunctions of the motor system of the masticatory organ, make the proper diagnosis of these disorders difficult. ${ }^{5}$ An example may be the presence of the myofascial component (characteristic of MFPS - myofascial pain syndrome) also in other pain syndromes, such as cervical spine pain syndrome, tension headache or pain in the area of the temporomandibular joints. MFPS occurs in up to $55 \%$ of the head and neck pain sufferers. The myofascial pain syndrome is also associated with limited movement in the joints, stiffness and weakening of muscle strength. ${ }^{15}$

In order to work out a practical systematization of diseases of the temporomandibular joints, a classification was created that derives from the division used in the International Research Diagnostic Criteria for Temporomandibular Disorders Consortium Network. It distinguishes three types of clinical and aetiological disorders of the temporomandibular joints: muscular and facial pain, internal disorders, and degenerative disease. ${ }^{16}$ In the case of myofacial pain, there are symptoms such as muscle tenderness and increased muscle tension, which are often related to the emotional state of the patient. Pain associated with internal disorders occurs in the case of abnormal mobility of the intracapsular structures of the temporomandibular joints, i.e. the articular disc. Pain in osteoarthritis is related to the destruction of the articular surfaces, which can be visualized on radiographs. ${ }^{17}$ Muscle pain and joint pain arise in the course of other mechanisms. Muscle pain arises as a result of increased muscle activity, which puts pressure on the blood vessels, which causes the release of substances that trigger the pain reaction, e.g. lactic acid, bradykinin, serotonin, glutamine. Joint pain results, among others, from the displacement of intra-articular structures, triady" mogą towarzyszyć objawy chorobowe innych narządów z sąsiednich okolic np. bóle głowy, bóle gałki ocznej i oczodołu, wysadzenie gałki ocznej, zaburzenia otolaryngologiczne w tym bóle ucha, szumy uszne. Wzajemne relacje czynnościowe poszczególnych struktur układu stomatognatycznego i narządów sąsiednich okolic anatomicznych oraz złożona etiologia dysfunkcji układu ruchowego narządu żucia powodują, że właściwa diagnostyka tych zaburzeń może sprawiać wiele trudności. ${ }^{5}$ Przykładem może być występowanie komponenty mięśniowo-powięziowej (charakterystycznej dla MFPS - myofascial pain syndrome czyli zespołu bólu mięśniowo-powięziowego) także w innych zespołach bólowych, takich jak zespół bólowy szyjnego odcinka kręgosłupa, napięciowy ból głowy czy właśnie ból w okolicy stawów skroniowo-żuchwowych. MFPS występuje nawet u 55\% osób cierpiących na ból głowy i szyi. Zespołowi bólu mięśniowo-powięziowego towarzyszą również ograniczenie ruchu w stawach, sztywność i osłabienie siły mięśniowej. ${ }^{15}$

W celu praktycznego usystematyzowania chorób stawów skroniowo-żuchwowych, stworzono klasyfikację wywodzącą się z podziału używanego w Badawczych Kryteriach Diagnostycznych (International Research Diagnostic Criteria for Temporomandibular Disorders Consortium Network). Wyróżnia ona trzy typy kliniczno-etiologiczne zaburzeń stawów skroniowo-żuchwowych: ból mięśniowo-twarzowy, zaburzenia wewnętrzne, choroba zwyrodnieniowa. ${ }^{16} \mathrm{~W}$ przypadku bólu mięśniowo-twarzowego występują objawy, takie jak: tkliwość mięśni oraz ich zwiększone napięcie, które związane są często z emocjonalnym stanem pacjenta. Ból związany z zaburzeniami wewnętrznymi, pojawia się $\mathrm{w}$ przypadku nieprawidłowej ruchomości struktur wewnątrztorebkowych stawów skroniowo-żuchowowych tj. krążka stawowego. Ból w chorobie zwyrodnieniowej występuje w związku ze zniszczeniem powierzchni stawowych, co uwidocznić 
which results in joint overload, which in turn implies pain. ${ }^{13}$

Nowadays, scientists have observed more frequent overload of chewing muscles as well as other head and neck muscles (which lead to problems with the TMJ or intensify existing disorders of its structures) among singers, musicians playing string instruments and also musicians playing wind instruments. ${ }^{18,19}$ According to Attallah et al. multifactorial aetiology and absence of direct causal relationship between one specific factor and the masticatory organ disorders make it difficult to evaluate how far just playing the wind instrument affects developing TMD. However, many researchers have observed among musicians who played instruments that needed to be held in the area of the arms and lower jaw (wind, string) and singers, more frequent overloads of the masticatory muscles and other muscles of the head and neck, which caused problems in the temporomandibular joints, or exacerbated the existing disorders in the area of the temporomandibular joint. ${ }^{20}$ Some authors discuss the real direct influence of playing the wind instrument on the occurrence of TMD, but others stress the unquestioned correlation between playing the wind instrument, (especially the oboe and the clarinet) or string instrument, and the TMJ disorders. ${ }^{21}$

Rodriguez-Lozano et al. pointed out that among problems of the head and neck area, the most common problem of musicians is TMD. Moreover, due to forced protrusive position of the mandible when a brass instrument is played, this group of musicians suffers the most often from bruxism and TMD. As a form of treatment, the wearing of relaxation occlusal splint at night, stress control and taking antiinflammatory drugs were suggested. In these studies, sound symptoms were the most frequent among the tuba and the trumpet players. ${ }^{22}$ After analysing the results of the survey, it was also observed that the probable można w badaniu radiologicznym. ${ }^{17}$ Ból mięśniowy oraz ból stawowy powstają w przebiegu innych mechanizmów. Ból mięśniowy powstaje w wyniku zwiększonej aktywności mięśniowej, która wywołuje ucisk na naczynia krwionośne, co powoduje uwalnianie substancji wyzwalających reakcję bólową np. kwas mlekowy, bradykinina, serotonina, glutamina. Ból stawowy wynika między innymi z przemieszczenia struktur wewnątrzstawowych, co skutkuje przeciążeniem stawu, który implikuje dolegliwości bólowe. ${ }^{13}$

Współczesne piśmiennictwo podaje, że zaburzenia w obrębie układu stomatognatycznego należą do grupy schorzeń, na które szczególnie mogą być narażeni muzycy grający na instrumentach dętych. ${ }^{18,19}$ Jak podają Attallah i wsp. wieloczynnikowa etiologia i brak prostego związku przyczynowo-skutkowego pomiędzy jednym konkretnym czynnikiem a zaburzeniami w obrębie narządu żucia, utrudnia ocenę faktycznego wpływu samej gry na instrumencie dętym na powstanie TMD (temporomandibular disorder). Jednakże wielu badaczy zaobserwowało u muzyków grających na instrumentach, które wymagały ich utrzymania w okolicy ramion i żuchwy (dętych, strunowych) oraz u śpiewaków, częstsze występowanie przeciążeń mięśni żucia oraz pozostałych mięśni głowy i szyi, które powodowały pojawienie się problemów w obrębie stawów skroniowo-żuchwowych lub nasilały już istniejące zaburzenia w obszarze stawu skroniowo-żuchwowego. ${ }^{20}$ Niektórzy autorzy polemizują co do rzeczywistego bezpośredniego wpływu gry na instrumencie na wystapienie TMD, a inni podkreślają bezsprzeczną korelację gry na instrumentach dętych (szczególnie obój i klarnet) i strunowych z wystąpieniem zaburzeń w obrębie stawów skroniowo-żuchwowych. ${ }^{21}$

Rozdriguez-Lozano i wsp. podają, że wśród problemów występujących w okolicy głowy i szyi, najczęstszą dolegliwością u muzyków jest TMD. Ponadto autorzy pracy podkreślają, 
bruxism symptoms were often noticed among musicians (about 30\%), but there was no influence of the type of the wind instrument (brass/wood) on more frequent teeth grinding, clenching or occlusal wear. However, the study showed that brass instrument players practise much more, which can have an impact on muscles hypertension and can lead more often to bruxism, as the quoted authors suggested. ${ }^{22}$ Moreover, among musicians playing brass instruments, there were more professional musicians who played daily and practised for more than four hours a day.

Among other symptoms, a single crackle suggests front dislocation of the mandibular disc without blocking. Articular crepitus may be a result of degeneration, when the joint space narrows, causing friction of joint surfaces and the disc. Crackles are relevant to abnormal dislocation of the joint disc during movements of the mandible. ${ }^{23}$ Respondents reported all types of sound symptoms, which can be the basis for the conclusion that wind instrument musicians may suffer from internal disorders as well as degenerate disease.

According to Cavalcanti de Queiroz et al. the initial factor of TMD in professional musicians was often stress associated with an important performance. Moreover, the authors noticed that during playing musicians had to maintain a body position, even detrimental one, for a long time and also they excessively clenched their teeth on playing. Abnormal position helping to hold the instrument by abuting it on the mandible, and also the necessity of blowing the instrument in an appropriate way in protrusive position of the mandible, making the musician overstep the anatomical limit of mobility of the TMJ structures, leads to facial pain and TMJ disorders. Many hours of repeated play demanding unnatural hyperactivity of muscles, that produces the air vibration, predisposes to TMD. The occurrence of TMJ disorders, among musicians playing wind and string instruments że najczęściej na bruksizm i TMD cierpią muzycy grający na instrumentach dętych blaszanych, ze względu na konieczność utrzymania żuchwy w pozycji protruzyjnej. Jako formę leczenia zalecono użytkowanie szyny relaksacyjnej w nocy, kontrolę stresu oraz leki przeciwzapalne. Objawy dźwiękowe występowały najczęściej u osób grających na tubie i trąbce ${ }^{22}$. Na podstawie analizy własnego badania ankietowego również stwierdzono stosunkowo częste występowanie objawów bruksizmu (30\%) wśród muzyków, jednakże nie zauważono, aby rodzaj instrumentu dętego (blaszany/drewniany) wpływał znacząco na występowanie częstszego zgrzytania, zaciskania czy starcia zębów. Badanie pokazało natomiast, że osoby grające na instrumentach dętych blaszanych zdecydowanie więcej ćwiczą, co może prowadzić do zwiększonego napięcia mięśniowego i sugerowanego przez cytowanych autorów ${ }^{22}$ częstszego diagnozowania bruksizmu. Ponadto wśród osób wybierających grę na blaszanym instrumencie dętym, znalazło się więcej profesjonalnych muzyków, grających na co dzień zawodowo i trenujących ponad 4 godziny dziennie.

Spośród innych objawów - dźwiękowe w postaci pojedynczego trzasku sugerują możliwość doprzedniego przemieszczenia krążka bez zablokowania. Trzeszczenia mogą być spowodowane przez zwyrodnienia, gdzie dochodzi do zmniejszenia szpary stawowej i wzajemnego tarcia powierzchni stawowych i krążka. Przeskakiwania związane sa z nieregularnym przemieszczaniem się krążka stawowego w trakcie ruchów żuchwy. ${ }^{23}$ Ankietowani zgłaszali występowanie wszystkich $\mathrm{z}$ wymienionych rodzajów dolegliwości dźwiękowych, co pozwala wysnuć wnioski, że muzycy grający na instrumentach dętych mogą rozwijać zarówno zaburzenia wewnętrzne, jak również cierpieć $\mathrm{z}$ powodu choroby zwyrodnieniowej.

Cavalcanti de Queiroz i wsp. twierdzą, że czynnikiem inicjującym występowanie TMD u profesjonalnych muzyków często jest stres 
(especially: the trumpet, the trombone, the tuba, the violin, the alto) and singers, were observed. ${ }^{24}$

Yasuda et al. in their research among Japanese high school students playing wind instruments confirmed a definitely higher percentage of musicians with TMD in comparison with the control group. Women players and musicians playing for the highest number of hours a day, and woodwind instruments players obtained higher results, which confirms conclusions of this study. In electromyographic examination they noticed hypertension of the head and neck muscles (masseter muscle, sternocleidomastroid muscle, trapezius muscle), especially in a group of musicians playing brass instruments. ${ }^{25}$ Factors which affect developing masticatory organ disorder include sleep dysfunction and active night bruxism. ${ }^{26}$ Analysis of data from this study demonstrated that respondents particularly often indicated occurrence of remittent headaches as well as intensified neck ache and neck muscles spasm. In the research, the most common muscle pain was observed by professionals, woodwind players and women players. According to AngelsCebriá et al., musicians often suffered from musculoskeletal problems. Depending on the type of instrument, different muscles of a patient's body may be affected. In the case of people who played woodwind instruments, the authors highlighted that the most frequent complaints involved: the hands, the wrists and the forearms. This problem especially concerns the clarinet, the oboe and the flute players. However, brass instrument musicians most often suffer from problems connected with mouth muscles, especially the orbicularis oris muscle. "Crack of the orbicularis oris muscle" known as Satchmo syndrome may occur. Trumpet players are the most vulnerable because of the high air pressure, which is needed during playing. This problem also concerns the French horn and the trombone players. According to the authors, the związany z ważnym wystąpieniem, np. w orkiestrze symfonicznej. Ponadto autorzy zauważają, że muzycy podczas przedstawienia muszą utrzymywać niekiedy wręcz szkodliwe pozycje ciała przez długi czas, a także nadmiernie zaciskają zęby podczas gry. Nieprawidłowa pozycja zarówno służąca utrzymaniu instrumentu poprzez oparcie o żuchwę, a także konieczność zadęcia w odpowiedni sposób przy doprzedniej pozycji żuchwy, wymuszające wręcz przekroczenie anatomicznego limitu ruchomości poszczególnych struktur, powodują ból okolicy twarzy oraz prowadzą do zaburzeń stawowych. Wielogodzinne, powtarzane ćwiczenia gry na instrumencie, wymagające zwiększonej nienaturalnej aktywności mięśniowej wprowadzającej powietrze w wibracje predysponują do rozwinięcia TMD. Zaobserwowano występowanie zaburzeń w stawach skroniowo-żuchwowych w grupie muzyków grających na instrumentach dętych oraz strunowych (zwłaszcza: trąbka, puzon, tuba, skrzypce, altówka) a także wśród wokalistów. $^{24}$

Yasuda i wsp. w badaniach przeprowadzonych wśród japońskich uczniów szkół średnich grających na instrumentach dętych, stwierdzili zdecydowanie większy odsetek muzyków z TMD w porównaniu z osobami z grupy kontrolnej. Znacznie wyższe wyniki uzyskano wśród kobiet, osób grających najwięcej godzin dziennie oraz muzyków grających na instrumentach dętych drewnianych, co potwierdza wyniki otrzymane w materiale własnym. W badaniu elektromiograficznym stwierdzono również wyraźnie zwiększone napięcie mięśni głowy i szyi (m.masseter, m. sternocleidomastoideus, m. trapezius), szczególnie w grupie muzyków, grających na instrumentach dętych blaszanych. ${ }^{25}$ Do rozwoju dysfunkcji układu ruchowego narządu żucia przyczyniać mogą się również różnego rodzaju zaburzenia snu, a także aktywny bruksizm nocny. ${ }^{26}$ Analiza własnych danych wykazała, że w grupie badanej respondenci szczególnie często zgłaszali 
TMJ disorders were much more characteristic of brass instruments players, due to active and persistent symptoms occurring during everyday practice and concerts. ${ }^{27}$

According to Głowacka et al. many years of wind instrument practice may lead to development of malocclusion or masticatory organ deformation. The authors noticed that the type of mouthpiece which the musicians used had particular influence. Playing the brass instrument requires putting the mouthpiece into the mouth, whereas playing woodwind instrument requires placing the mouthpiece between lips and softly resting it on the incisors. Besides, playing wind instrument causes craniomandibular dysfunction, which leads to neck, back and arms muscles pain. Exercises of the head and neck muscles before practice are advisable as a solution to reduce pain. It should tone up muscles of the lips, the tongue and the mandible. The authors of this study also propose the use of prophylactic relaxation plates in professional musicians in order to eliminate the dysfunctions of the masticatory system. ${ }^{28}$ Intraoral pressure among trumpet players may achieve $25 \mathrm{kPa}$ and cause counteractive mastcatory muscles force at levels over $100 \mathrm{~N} .{ }^{29}$ In this research, the idea of a warm-up before the practice was also touched upon. It turned out that people who did warm-ups, suffered less from TMJ disorders. Warming muscles up before the practice and doing breathing exercises should help in keeping balance of muscle forces. Moreover, it is advised to have regular breaks during a long practice, which can also reduce the risk of stomatognathic system disorders. ${ }^{30}$

It should be underlined that musicians need to inform physicians about the fact of playing an instrument, the technique and frequency of playing, which can help to make a correct diagnosis and implement appropriate preventive and therapeutic procedures. ${ }^{22}$ Depending on występowanie dolegliwości w postaci nawracającego bólu głowy oraz nasilonego bólu i skurczu mięśni szyi. W badaniu najczęściej dolegliwości o charakterze bólu mięśniowego, obserwowali u siebie: zawodowcy, muzycy grający na instrumentach dętych drewnianych oraz kobiety. Jak podaje Angels-Cebriá i wsp. u muzyków mogą występować problemy mięśniowo-szkieletowe. W zależności od rodzaju instrumentu, procesami chorobowymi dotknięte mogą być inne obszary mięśniowe pacjenta. W przypadku osób, grających na instrumentach dętych drewnianych, autorzy podkreślają, że najczęstsze dolegliwości występują w dłoni, nadgarstku oraz przedramionach. Szczególnie problem ten dotyka klarnecistów, oboistów oraz flecistów. Jednakże muzycy grający na instrumentach dętych blaszanych najczęściej cierpią z powodu problemów w obrębie mięśni okolicy jamy ustnej, a zwłaszcza m.orbicularis oris. Wystąpić może tzw. „pękniecie m. okrężnego ust" nazywane syndromem Satchmo. Najbardziej narażeni są trębacze, ze względu na wymagane wytworzenie wysokiego ciśnienia podczas gry. Dotyczy to również osób grających na rogu francuskim oraz puzonie. Zaburzenia w obrębie stawów skroniowo-żuchwowych są znacznie bardziej znamienne dla muzyków grających na instrumentach dętych blaszanych, z powodu zaktywowanych i utrzymujących się objawów podczas codziennej praktyki oraz koncertów. ${ }^{27}$

Głowacka i wsp. zwracają uwagę, że wieloletnia gra na instrumencie dętym może prowadzić do powstania wad zgryzu oraz deformacji w obrębie układu stomatognatycznego. Szczególny wpływ ma rodzaj ustnika, z którego korzysta muzyk. Gra na instrumencie dętym blaszanym wymaga włożenia ustnika do ust, natomiast na dętym drewnianym polega na umieszczeniu ustnika pomiędzy wargami z lekkim oparciem o siekacze. Ponadto gra na instrumencie dętym wywołuje dysfunkcje czaszkowo-żuchwowe, co powoduje również bóle mięśni szyi, ramion 
individual conditions of a patient, the position and the technique of playing, the dentist on the basis of observation and understanding the influence of posture on the occurrence of head and neck problems, should inform the patient about ways of preventing stomatognathic system disorders, and in the case of their occurrence, should implement correct treatment for every single case. ${ }^{24,31,32}$

\section{Conclusion}

1 The wind instrument players constitute a group of patients in whom disorders of the $\mathrm{TMJ}$ and musculo-motor problems in the area of the head and neck may occur. Reported ailments indicate that playing wind instruments may predispose to symptoms of dysfunction, including myofascial pain, internal disorders, degenerative conditions and problems in the musculoskeletal system of the head and neck.

2. Among musicians, those who play professionally, practise playing for many hours every day and chose a woodwind instrument are particularly prone to the occurrence of the above-mentioned disorders.

3. A warm-up before playing may help to prevent some TMJ diseases.

4. Musicians who play wind instruments constitute a group of patients who require particular dental care and whose awareness about possibilities of TMJ problems occurrence should be increased.

5. Proper education of dentists with implementation of relevant procedures and teaching preventive habits may reduce the number of patients suffering from stomatognathic system disorders among wind instruments players. i barków. Sugerowane jest wykonywanie przez muzyków ćwiczeń mięśni twarzy, jako formę przygotowania przed rozpoczęciem gry, służącym redukcji bólu poprzez wzmocnienie siły przede wszystkim mięśni ust, języka i żuchwy. Autorzy pracy proponują również zastosowanie profilaktycznych płytek relaksacyjnych u profesjonalnych muzyków, celem wyeliminowania powstania dysfunkcji narządu żucia. ${ }^{28}$ Ciśnienie wewnątrzustne u trębaczy może wynosić nawet $25 \mathrm{kPa}$, a w związku z tym siły przeciwdziałające mięśni warg często przekraczają wartość $100 \mathrm{~N} .{ }^{29} \mathrm{~W}$ badaniu własnym poruszono również zagadnienie tzw. rozgrzewki przed grą. Okazuje się, że osoby, które ją stosowały rzadziej cierpiały z powodu dolegliwości w obrębie stawów skroniowo-żuchwowych. Rozgrzewanie mięśni przed grą oraz wykonywanie ćwiczeń oddechowych, powinno pomóc w zapewnieniu odpowiedniej równowagi mięśniowej. Ponadto zalecane jest wykonywanie regularnych przerw podczas długotrwałej gry, co również ma za zadanie zmniejszyć ryzyko wystąpienia zaburzeń układu stomatognatycznego. ${ }^{30}$

Podkreślić należy konieczność informowania lekarzy stomatologów o fakcie grania na instrumencie oraz technice i częstości ćwiczeń, co pozwoli na prawidłowe stawianie diagnozy i wdrażanie odpowiedniego leczenia. ${ }^{22} \mathrm{~W}$ zależności od indywidualnych warunków pacjenta oraz od pozycji i techniki gry muzyka, lekarz dentysta na podstawie obserwacji i analizie wpływu postury na obecność problemów w obrębie głowy i szyi, powinien poinformować pacjenta o sposobach profilaktyki zaburzeń układu stomatognatycznego, a w razie ich wystapienia wdrożyć właściwy dla danego przypadku plan leczenia. ${ }^{24,31,32}$

\section{Wnioski}

1. Muzycy grający na instrumentach dętych stanowią grupę pacjentów, u których występować mogą dolegliwości i zaburzenia 
ze strony stawów skroniowo-żuchwowych. Zgłaszane dolegliwości wskazują, że gra na instrumentach dętych może predysponować do występowania objawów dysfunkcji, w tym bólu mięśniowo-powięziowego, zaburzeń wewnętrznych, stanów zwyrodnieniowych oraz problemów w obrębie układu mięśniowo-ruchowego głowy i szyi.

2. Wśród muzyków szczególnie narażeni na występowanie wyżej wymienionych zaburzeń są: muzycy grający zawodowo, osoby ćwiczące grę codziennie przez wiele godzin oraz muzycy, którzy wybrali instrument dęty drewniany.

3. Rozgrzewka przed grą może pomóc w zapobieganiu dolegliwościom w obrębie stawów skroniowo-żuchwowych.

4. Muzycy grający na instrumentach dętych należą do grupy pacjentów, która wymaga szczególnej opieki stomatologicznej oraz zwiększenia świadomości odnośnie możliwości występowania dolegliwości w obrębie stawów skroniowo-żuchwowych.

5. Właściwa edukacja oraz wdrożenie ewentualnych działań i nawyków profilaktycznych, mogą pozwolić na redukcję liczby przypadków pacjentów, cierpiących z powodu dolegliwości w obrębie układu stomatognatycznego, w grupie osób grających na instrumentach dętych.

\section{References / Piśmiennictwo}

1. Prośba-Mackiewicz M, Wytrykowska A, Hebel $J$ : Analiza wpływu czynników etiopatogennych o charakterze socjalnym na stopień nasilenia dysfunkcji układu stomatognatycznego. Protet Stomatol 2012; LXII, 4: 237-243.

2. Baron $S$, Walawender T, Baron A, Walawender $I$ : Estetyczno-funkcjonalna rehabilitacja układu ruchowego narządu żucia. Protet Stomatol 2011; LXI, 6: 459-465.

3. Kurpiel P, Kostrzewa-Janicka J: Dysfunkcja układu ruchowego narządu żucia - etiologia i klasyfikacja schorzeń. Przegląd piśmiennictwa, Nowa Stomat 2014; 2: 95-99.

4. Kleinrok M: Zaburzenia czynnościowe układu ruchowego narządu żucia. Wydawictwo Czelej, Lublin 2012, 16-19.

5. Majchrzak K, Burzyńska B, KostrzewaJanicka J, Mierzwińska-Nastalska E: Ocena czynników miejscowych i ogólnych mających wpływ na układ ruchowy narządu żucia. Protet Stomatol 2011; LXI, 3: 196-203.

6. Steinmetz A, Scheffer I, Esmer E, Delank KS, Peroz I: Frequency, severity and predictors of playing-related musculoskeletal pain in professional orchestral musicians in Germany. Clinical Rheumat 2015; 34, 5: 965-973.

7. Gotouda A, Yamaguchi T, Okada K, Matsuki $T$, Gotouda S, Inoue N: Influence of playing wind instruments on activity of masticatory. Article First Published Online 2007, Doi: 10.1111/J.1365-2842.2007.01765.X.

8. Yeo DK, Pham TP, Baker J, Porters S: Specific orofacial problems experienced by musicians. Aust Dent J 2002; 47, 1: 2-11.

9. Kostrzewa-Janicka J, Magdziak M, Meredyk $K$, Jurkowski P, Mierzwińska-Nastalska E: Ocena leczenia z zastosowaniem indywidualnej relaksacyjnej szyny zgryzowej u osób z objawami bólu mięśniowo-powięziowego. Protet Stomatol 2014; LXIV, 6: 406-416.

10. Shibin Y, Xianghui X, Shuhui L, Zhaofeng M, Feifei L, Meiqing W, Yongqi L: Locally synthetized estrogen plays an important role in the development of tmd. Med Hypothese 2009; 72: 720-722.

11. Szymańska D: Ocena zaburzeń stawu skro- 
niowo-żuchwowego w aspekcie aktywności bioelektrycznej. XI Konferencja Naukowa Majówka Młodych Biomechaników im. Prof. Dagmary Tejszerskiej, APB 2014; 8: 151-156.

12. Majewski S, Wieczorek A, Loster J, Pihut M: Mięśnie żucia i stawy skroniowo-żuchwowe w aspekcie fizjologicznych funkcji układu stomatognatycznego. Protet Stomatol 2010; LX, 1: 10-16.

13. Cairns BE: Pathophysiology of tmd pain basic mechanisms and their implications for pharmacotherapy. J Oral Rehabil 2010; 37: 391-410.

14. Dupas PH: Dysfunkcja czaszkowo-żuchwowa. Od diagnozy - po szynę zgryzową, PZWL Warszawa 2009.

15. Chochowska M, Klonowska J, Ogrodowczyk $R$, Marcinkowski JT: Napięciowe bóle głowy a zespól bólu mięśniowo-powięziowego. Część I. Klasyfikacja, etiopatogeneza, kryteria diagnostyczne. Hygeia Public Health 2015; 50, 2: 283-287.

16. Osiewicz MA, Lobbezoo F, Loster BW, Wilkosz $M$, Naeije M, Ohrbach R: Badawcze kryteria diagnostyczne zaburzeń czynnościowych układu ruchowego narządu żucia bkd/zcurnż polska wersja dwuosiowego systemu diagnostycznego zcurnż. Protet Stomatol 2010; LX, 6: 433-444.

17. Wanyura H, Stopa Z, Brudnicki A i wsp.: Wstępna kliniczno-etiologiczna ocena osób leczonych w O.A.S.S.Ż. z powodu chorób stawu skroniowo-żuchwowego. Czas Stomatol 2001; 54, 790-799.

18. Cavalcanti de Queiroz JR, Mollica FB, Benetti P, Maximo de Araujo AM, Valera MC: Degree of chronic orofacial pain associated to the practice of musical instruments in orchestra's participants. Indian J Dent Res 2014; 25, 1 : 28-31.

19. Lederman RJ: Neuromuscular and musculoskeletal problems in instrumental musicians. Muscle\&Nerve, 2003 - Wiley Online Library.
20. Attallah MM, Visscher CM, Van Selms MK, Lobbezoo F: Review Is there an association between temporomandibular disorders and playing a musical instrument? A review of literature. J Oral Rehabil 2014; 41, 7: 532-541.

21. Taddey JJ: Musicians and temporomandibular disorders: prevalence and occupational etiologic considerations. Cranio 1992; 10: 241-244.

22. Rodríguez-Lozano FJ, Sáez-Yuguero MR, Bermejo-Fenoll A: Orofacial problems in musicians: a review of the literature. MPPA 2011; 26, 3: 150 .

23. Mierzwińska-Nastalska E: Diagnostyka układu ruchowego narządu żucia. Zasady rekonstrukcji zwarcia. Med Tour Press, 2009.

24. Cavalcanti de Queiroz JR i wsp.: Degree of chronic orofacial pain associated to the practice of musical instruments in orchestra's participants. Original research 2014; 25, 1: 28-31.

26. Yasuda E, Honda K, Hasegawa Y, Matsumura E, Fujiwara M, Hasegawa M, Kishimoto H: Prevalence of temporomandibular disorders among junior high school students who play wind instruments. Int J Occup Med Environ Health 2016; 29, 1: 69-76.

27. Michael TS, Wickwire EM, Edward GG, Robert RE, Luis FB, Peterson S, Brendan K, Haythornthwaite JA: Sleep disorders and their association with laboratory pain sensitivity in temporomandibular joint disorder. Sleep 2009; 32, 6: 779-788.

28. Àngels Cebriá M, Pérez-Soriano P, Camacho CI, Llana Belloch S, Cortell-Tormo JM: Playing-related musculoskeltal disorders in woodwind, brass and percussion players: a review. J Hum Sport Exerc 2010; 5, 1: 94-100.

29. Gtowacka A, Matthews-Kozanecka M, Kawala $M$, Kawala B: The impact of the long-term playing of musical instruments on the stomatognathic system - review. Adv Clin Exp Med 2014; 23, 1: 143-146.

30. Steinmetz A, Ridder P, Methfessel G, Musche B: Professional musicians with craniomandibular 
dysfunctions treated with oral splint. Cranio 2009; 27, 4: 221-230.

31. Žuškin E, Schachter EN, Kolčić I, Polašek O, Mustajbegović J, Arumugam U: Health problems in musicians - a review. Acta Dermatovenerol Croat 2005; 13, 4: 247-251.

32. Joubrel I, Robineau S, Petrilli S, Gallien $P$, Readaptaion A: Pathologies de l'appareil locomoteur du muscicien: Etude
Epidemiologique. Med Phys 2001; 44: 72-80. 33. Bejjani FJ, Kaye GM, Benham M: Musculoskeletal and neuromuscular condition of instrumental musicians. Arch Phys Rehabil 1996; 77: 406-413.

Zaakceptowano do druku: 4.03.2021 r.

Adres autorów: 02-097 Warszawa, ul. Binieckiego 6.

(c) Zarząd Główny PTS 2021. 